\title{
Morphological and Physiological Performances of 18 Soybean Varieties Exposed to Salinity Stress
}

\section{Penampilan Morfologi dan Fisiologi pada 18 Varietas Kedelai pada Cekaman Salinitas}

\section{Hesti Pujiwati ${ }^{1 *}$, Usman Kris Joko Suharjo ${ }^{1}$, Wuri Prameswari ${ }^{1}$, Muhimmatul Husna ${ }^{1}$, Bambang Gonggo Murcitro ${ }^{2}$, Sempurna Ginting ${ }^{3}$, and Edi Susilo ${ }^{4}$}

\author{
${ }^{1}$ Agroecotechnology Study Program, Department of Agronomy, Faculty of Agriculture, Bengkulu University \\ St. Raya Kandang Limun, Bengkulu City 38371, Indonesia \\ ${ }^{2}$ Soil Science Study Program, Department of Agronomy, Faculty of Agriculture, Bengkulu University \\ St. Raya Kandang Limun, Bengkulu City 38371, Indonesia \\ ${ }^{3}$ Plant Protection Study Program, Department of Plant Protection, Faculty of Agriculture, Bengkulu University \\ St. Raya Kandang Limun, Bengkulu City 38371, Indonesia \\ ${ }^{4}$ Agrotechnology Study Program, Faculty of Agriculture, Ratu Samban University \\ St. Jenderal Sudirman No. 87 Arga Makmur, Northern Bengkulu, Indonesia
}

Received 30 September 2021/Accepted 19 November 2021

\begin{abstract}
Increasing soybean production can be done by growing the crops in marginal soil, such as saline soil. Therefore, salinetolerant genotypes are important to support the cultivation. The objective of the experiment was to evaluate the performance of 18 soybean varieties grown under salinity stress. The experiment was done from May to July 2021 at the greenhouse of the Department of Agronomy, Faculty of Agriculture, Bengkulu University, about $10 \mathrm{~m}$ above sea level. Soybean seedlings were grown in $10 \mathrm{~cm}$ diameter plastic pots fertilized with $\mathrm{AB}$-mix solutions supplemented with 0 or $6 \mathrm{dSm}{ }^{-1} \mathrm{NaCl}$ for 15 days. The growth and stress-tolerant index of the seedlings were measured. The results showed that soybean variety had different growth as responses to salinity. Moreover, salinity stress imposed at $6 \mathrm{dSm}{ }^{-1} \mathrm{NaCl}$ significantly reduced crops growth and promoted leaf senescence. We found that 18 soybeans varieties were classified as salinity tolerant at $6 \mathrm{dSm} \mathrm{S}^{-1}$.
\end{abstract}

Keywords: saline, soybean varieties, tolerant

\section{ABSTRAK}

Peningkatan produksi kedelai dapat dilakukan dengan menanam tanaman di lahan marginal, seperti tanah salin. Upaya yang dapat dilakukan untuk mengatasi permasalahan tersebut salah satunya dengan menyeleksi tanaman yang toleran pada kondisi salin. Penelitian dilakukan pada bulan Mei-Juli 2021 di rumah kaca Departemen Agronomi, Fakultas Pertanian, Universitas Bengkulu, $10 \mathrm{~m}$ di atas permukaan laut. Penelitian ini bertujuan untuk mengevaluasi toleransi 18 varietas kedelai yang ditanam pada cekaman salinitas. Kedelai ditanam dalam pot plastik berdiameter $10 \mathrm{~cm}$ yang dipupuk dengan larutan AB-mix dengan perlakuan 0 dan $6 \mathrm{dSm}^{-1} \mathrm{NaCl}$ selama 15 hari dari cekaman salinitas. Pertumbuhan dan indeks toleran cekaman bibit diukur. Hasil penelitian menunjukkan bahwa varietas kedelai mempengaruhi pertumbuhan tanaman secara berbeda. Selain itu, cekaman salinitas secara nyata mengurangi pertumbuhan tanaman. Hasil penelitian menunjukkan bahwa 18 varietas kedelai tergolong pada toleran salinitas pada tingkat salinitas $6 \mathrm{dSm}{ }^{-1}$.

Kata kunci: salinitas, toleransi varietas kedelai

\section{INTRODUCTION}

Soybean (Glycine max L.) is one the most important crops for Indonesia after rice and corn (Badan Pusat Statistika, 2020). It is a good source for protein and

\footnotetext{
*Corresponding author. e-mail: hesti_pujiwati@unib.ac.id
}

inexpensive (Khojely et al., 2018), because of which the demand for soybean increases from time to time. It was 8.96 $\mathrm{kg}$ per kapita per year in 2018 and is expected to become $9.78 \mathrm{~kg}$ per kapita per year (Kementerian Pertanian, 2019). Unfortunately, the national production of soybean cannot fulfil the national demand, resulting in an increase impor volume yearly. Therefore, attempt to increase national 
soybean production is important. It can be done by increasing land productivity, increasing cropping intensity, and increasing land area for growing soybean (Rachman et al., 2013). Growing soybean at marginal land, including sandy soil affected by saline water, is one approach among many choices available.

Salinity is a sub-optimal condition in which the soil solution's electrical conductivity (EC) is $>4.0 \mathrm{dSm}^{-1}$ (about $40 \mathrm{mM} \mathrm{NaCl}$ ) resulted from salt accumulation in the soil, like $\mathrm{NaCl}$ and $\mathrm{Na}_{2} \mathrm{SO}_{4}$ (Muscolo et al., 2011). About $19.5 \%$, equal to 45 billion hectares of agricultural land globally, has been exposed to saline (Koro et al., 2012). In general, high salinity level causes ionic toxicity, osmotically stress, nutrient deficiency, and oxidative stress due to the production of free radicals (Rasool et al., 2013), membrane disorganization, a reduction in cell division (Farooq et al., 2015), change in metabolism rate and cell size (Zorb et al., 2019), which may reduce crop growth, development (Liang et al., 2017) and reduce in crop yield (Zorb et al., 2019), increasing $\mathrm{NaCl}$ levels outside the cell cause osmotically stress such as interruption of membranes and nutrient imbalance (Gupta and Huang, 2014). However, plants may respond to osmotically stress by accumulating organic compound, as osmoregulatory whose function is to maintain cell turgor (Kordrostami and Rabiei, 2019). Parihar et al. (2015) reported that an increase in $\mathrm{NaCl}$ uptake causes the accumulation of $\mathrm{Na}^{+}$and $\mathrm{Cl}^{-}$which intoxicate the whole plant.

Soybean is one of the legume crops sensitive to salinity stress of $\mathrm{Na}^{+}$(Le et al., 2021), having a lethal concentration of $5.0 \mathrm{mScm}^{-1}$ (Chinnusamy et al., 2005). The sprouting phase and seedling growth are the most sensitive phase of soybean to salinity stress (Ibrahim, 2016). Salinity stress causes morphological, physiological, and biochemical changes in the sprouting seedlings (Paparela et al., 2005; Ibrahim, 2016). Response of soybean genotypes or varieties to salinity stress is varies. Research results of Aini et al. (2014) the content of $\mathrm{Na}$ in leaves and roots eleven genotypes differently in stress salinity. In a similar case, the Taufiq et al. (2019) result's, identify of 202 soybean germplasm collections of Balitkabi to salinity stress discovered $52 \%$ intolerant, $36 \%$ tolerant at $4.7-8.4 \mathrm{dSm}^{-1}$ and others tolerant at salinity $8.8-15.4 \mathrm{dSm}^{-1}$.

The utilizing of soybean tolerance is an effort to increase soybean production in saline land, so it is necessary to researching soybean varieties under salinity to determine tolerant varieties. The determining of tolerant soybean is known from plant morphology and physiology. The objective of the experiment was to evaluate the morphology and physiology performance of 18 soybean varieties grown under salinity stress.

\section{MATERIALS AND METHODS}

The experiment was done from May to July 2021 at the greenhouse of the Department of Agronomy, Faculty of Agriculture, Bengkulu University, about $10 \mathrm{~m}$ above sea level. Plant materials used were 18 varieties of soybeans Anjasmoro, Derap 1, Detam 1, Detam 2, Devon 2, Dena 1, Deja 1, Deja 2, Devon 1, Dega 1, Detap 1, Grobogan, Dering 1, Gepak Kuning, Detam 4, Willis, Devatra 1, Devatra 2.

Soybean seeds were sown in a plastic pot $(10 \mathrm{~cm}$ in diameter) filled with sand. The sand was connected to nutrient solutions in the bucket located below the pot with a piece of flannel fabric, $2 \mathrm{~cm}$ wide and $10 \mathrm{~cm}$ long. The nutrient solution that contents of macro and micro nutrient was used for growth soybean nutrient needed. The nutrient solution was prepared by following Okhi (1987), using the following chemical: $0.24 \mathrm{mM} \mathrm{NH}_{4} \mathrm{NO}_{3}, 0.03 \mathrm{mM}\left(\mathrm{NH}_{4}\right)_{2} \mathrm{SO}_{4}, 0.1 \mathrm{mM}$ $\mathrm{K}_{2} \mathrm{HPO}_{4}, 0.088 \mathrm{mM} \mathrm{K} \mathrm{SO}_{4}, 0.38 \mathrm{mM} \mathrm{KNO}, 1.27 \mathrm{mM}$ $\mathrm{Ca}\left(\mathrm{NO}_{3}\right)_{2} \cdot 4 \mathrm{H}_{2} \mathrm{O}, 0.27 \mathrm{mM} \mathrm{Mg}\left(\mathrm{NO}_{3}\right)_{2} \cdot 4 \mathrm{H}_{2} \mathrm{O}, 0.14 \mathrm{mM} \mathrm{NaCl}$, $6.6 \mu \mathrm{MH}_{3} \mathrm{BO}_{3}, 5.1 \mu \mathrm{M} \mathrm{MnSO}_{4} \cdot 4 \mathrm{H}_{2} \mathrm{O}, 0.61 \mu \mathrm{MZnSO}_{4} .7 \mathrm{H}_{2} \mathrm{O}$, $0.16 \mu \mathrm{M} \mathrm{CuSO}{ }_{4} .5 \mathrm{H}_{2} \mathrm{O}, 0.1 \mu \mathrm{M} \mathrm{Na} \mathrm{Mo}_{7} \mathrm{O}_{9} .7 \mathrm{H}_{2} \mathrm{O}, 45 \mu \mathrm{M}$ $\mathrm{FeSO}_{4} \cdot 7 \mathrm{H}_{2} \mathrm{O}$-EDTA and $\mathrm{NaCl} 6 \mathrm{dSm}^{-1}$ solution. The equipments used for the experiment included plastic pot, $\mathrm{pH}$ meter, SPAD, and analytical balance.

The experiment used a completely randomized design, arranged in factorials, with two factors and three replications. The first factor was 18 soybean varieties. The second factor was salt solution levels, which were 0 and $6 \mathrm{dSm}^{-1}$.

Soybean seeds were germinated at the sandy media. Five days after planting (DAP), the seedlings were transplanted onto a $10 \mathrm{~cm}$ diameter plastic pot filled with sand. The pots were put in the tray bucket containing AB-mix solutions with salt $\left(6 \mathrm{dSm}^{-1} \mathrm{NaCL}\right)$ or without salt $\left(0 \mathrm{dSm}^{-1} \mathrm{NaCl}\right)$. The salty nutrient solutions were replaced every other day

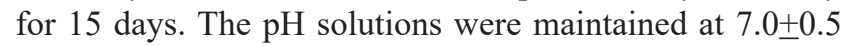
using either $1 \mathrm{M} \mathrm{HCl}$ or $1 \mathrm{M} \mathrm{NaOH}$. The temperature was held at $25 \pm 1{ }^{\circ} \mathrm{C}$.

The variable measured included plant height, leaf number, branch number, root length, leaf color were measured at 5, 10, and 15 days after treatment (DAT). At harvesting time (15 DAT), we measured, shoot fresh weight, fresh root weight, shoot dry weight, and root dry weight.

Soybean tolerance to salinity was determined by using the stress tolerance index (STI) formula introduced by Fisher and Maurer (1978), as follows:

$$
S=\frac{1-\left(\frac{Y}{Y p}\right)}{1-\left(\frac{X}{X p}\right)}
$$

Note:

$\mathrm{S}=$ sensivity index, $\mathrm{Y}=$ the average value of certain variables obtained from a variety exposed to stress, $Y p=$ the average value of certain variables obtained from a variety without stress, $\mathrm{X}=$ the average value of certain variables on all varieties exposed to stress, $\mathrm{Xp}=$ the average value of the certain variable on all varieties without stress.

Criteria: tolerance if $\mathrm{S}<0.5$, medium tolerance if $0.5<$ $\mathrm{S} \leq 1.0$, sensitive if $\mathrm{S} \geq 1.0$. The conclusion of the sensivity index was based on the average value of the sensitivity index for all of the variables. 
Data analysis was done by using analysis of variance (ANOVA), followed by mean separation analysis using Duncan's Multiple Range Test (DMRT) at $\alpha=5 \%$, when the ANOVA was significant $(\mathrm{P}<0.05)$.

\section{RESULTS AND DISCUSSION}

The results of ANOVA, soybean variety were significantly different in salinity in plant height, leaf number at 10 DAT, root fresh weight, shoot new weight, shoot dry weight, leaf greenness at $10 \mathrm{DAT}$. Salinity at $6 \mathrm{dSm}^{-1} \mathrm{NaCl}$ significantly affected all variables measured except for branch number and leaf greenness at 5 DAT.

\section{Different Responses of Soybean Variety}

Plant height varied among the variety tested. Detap-1 showed the highest crops at all sampling observations, while Wilis demonstrated the opposite (Table 1). Figure 1 showed there was reducing of the growth rate to soybean variety excepted Detam 4 variety. The greatest decrease in growth rate was Derap 1 by $84.15 \%$. According to Chen et al. (2018) the genotype variation of soybean indicated salinity respons is its growth rate. Trustinah et al. (2018) have researched about mung beans in salin soil with $11.4 \mathrm{dSm}^{-1}$ salinity, the response of plant that tolerant of salinity had a normal growth and no interference of height. In this respect, among the cultivar tested, the best growth was found in Detap-1. Furthermore, leaf numbers also varied among the varieties when measured at 10 DAT, in which the highest number was found in Devon-1 and Gepak Kuning (Table 1).

A crop performance is determined by the genetic capacity and environmental conditions where the crops are grown. Hamayun et al. (2010) reported salinity stress caused a reduction in gibberellic acid production, leading to a decrease in cell expansion, resulting in crop growth reduction. Salin stress also reduces photoassimilation of soybeans (Bai et al., 2019).

The greenness of leaf was measured at 5, 10, and 15 DAT. However, only at 10 DAT, the effect of variety was significantly different in which Devon-1 demonstrated the best value while Devatra-1 showed the worst (Table 2). The greenness value decreased at 15 DAT that effects of salinity soybean variety, except Detam 1 and Gepak Kuning varieties. Dhaiyashed and Sharad (2015) have stated that when exposed to saline conditions, sensitive genotypes will

Table 1. Plant height, leaf number, and branch number of 18 soybean varieties at 5, 10, and 15 DAT

\begin{tabular}{|c|c|c|c|c|c|c|c|c|c|}
\hline \multirow{2}{*}{ Varietas } & \multicolumn{3}{|c|}{ Plant height (cm) } & \multicolumn{3}{|c|}{ Leaf number (blade) } & \multicolumn{3}{|c|}{ Branch number } \\
\hline & 5 DAT & $10 \mathrm{DAT}$ & $15 \mathrm{DAT}$ & 5 DAT & $10 \mathrm{DAT}$ & $15 \mathrm{DAT}$ & 5 DAT & $10 \mathrm{DAT}$ & $15 \mathrm{DAT}$ \\
\hline Anjasmoro & 12.08abcde & $14.25 \mathrm{abc}$ & $15.58 \mathrm{ab}$ & 1.67 & $1.67 \mathrm{~cd}$ & 2.33 & 0.33 & 0.50 & 0.50 \\
\hline Derap 1 & $9.75 \mathrm{def}$ & $13.42 \mathrm{bcd}$ & $14.00 \mathrm{bcde}$ & 1.33 & $2.00 \mathrm{abcd}$ & 2.33 & 0.17 & 0.50 & 0.83 \\
\hline Detam 1 & $10.50 \mathrm{cdef}$ & $12.08 \mathrm{def}$ & $13.00 \mathrm{cdef}$ & 1.00 & $1.50 \mathrm{~d}$ & 1.50 & 0.00 & 0.00 & 0.00 \\
\hline Detam 2 & $10.83 \mathrm{bcdef}$ & $12.75 \mathrm{cde}$ & $13.92 \mathrm{bcde}$ & 1.67 & $2.17 \mathrm{abc}$ & 2.50 & 0.00 & 0.00 & 0.00 \\
\hline Devon 2 & $12.67 \mathrm{abc}$ & $14.42 \mathrm{ab}$ & $15.67 \mathrm{ab}$ & 1.67 & $2.00 \mathrm{abcd}$ & 2.33 & 0.00 & 0.00 & 0.00 \\
\hline Dena 1 & $9.50 \mathrm{ef}$ & $11.25 \mathrm{efg}$ & $11.67 \mathrm{fgh}$ & 1.17 & $1.67 \mathrm{~cd}$ & 2.00 & 0.00 & 0.00 & 0,33 \\
\hline Deja 1 & $10.33 \mathrm{cdef}$ & $11.75 \mathrm{def}$ & $13.25 \mathrm{cdef}$ & 1.33 & $1.83 \mathrm{bcd}$ & 2.00 & 0.00 & 0.00 & 0.00 \\
\hline Deja 2 & $10.17 \mathrm{cdef}$ & $11.75 \mathrm{def}$ & $12.75 \mathrm{def}$ & 1.50 & $1.67 \mathrm{~cd}$ & 2.17 & 0.17 & 0.50 & 0.67 \\
\hline Devon 1 & $12.50 \mathrm{abcd}$ & $15.00 \mathrm{ab}$ & $16.00 \mathrm{ab}$ & 1.67 & $2.50 \mathrm{a}$ & 2.67 & 0.17 & 0.17 & 0.33 \\
\hline Dega 1 & $11.17 \mathrm{bcdef}$ & $13.58 \mathrm{bcd}$ & $14.58 \mathrm{bcd}$ & 1.50 & $2.33 \mathrm{ab}$ & 2.17 & 0.00 & 0.00 & 0.00 \\
\hline Detap 1 & $14.25 \mathrm{a}$ & $15.83 a$ & $16.83 a$ & 1.33 & $2.00 \mathrm{abcd}$ & 2.17 & 0.00 & 0.00 & 0.17 \\
\hline Grobogan & $11.50 \mathrm{bcdef}$ & $13.83 \mathrm{abcd}$ & $15.08 \mathrm{abc}$ & 1.50 & $2.33 \mathrm{ab}$ & 2.50 & 0.00 & 0.17 & 0.17 \\
\hline Dering 1 & $9.92 \mathrm{cdef}$ & $10.33 \mathrm{fg}$ & $11.17 \mathrm{fgh}$ & 1.33 & $1.83 \mathrm{bcd}$ & 2.00 & 0.00 & 0.00 & 0.00 \\
\hline Gepak Kuning & $9.75 \mathrm{def}$ & $11.08 \mathrm{efg}$ & $12.25 \mathrm{def}$ & 1.50 & $2.50 \mathrm{a}$ & 2.33 & 0.00 & 0.00 & 0.00 \\
\hline Detam 4 & $9.58 \mathrm{ef}$ & $10.25 \mathrm{fg}$ & $11.25 \mathrm{fgh}$ & 1.17 & $1.67 \mathrm{~cd}$ & 1.83 & 0.00 & 0.00 & 0.00 \\
\hline Willis & $8.83 \mathrm{f}$ & $9.58 \mathrm{~g}$ & $10.42 \mathrm{gh}$ & 1.83 & $2.00 \mathrm{abcd}$ & 2.00 & 0.00 & 0.00 & 0.00 \\
\hline Devatra 1 & $13.33 \mathrm{ab}$ & $12.67 \mathrm{cde}$ & $13.25 \mathrm{cdef}$ & 1.50 & $2.17 \mathrm{abc}$ & 2.00 & 0.00 & 0.33 & 0.33 \\
\hline Devatra 2 & $9.83 \mathrm{def}$ & $10.00 \mathrm{fg}$ & $10.17 \mathrm{~h}$ & 1.50 & $2.00 \mathrm{abcd}$ & 2.00 & 0.00 & 0.00 & 0.00 \\
\hline
\end{tabular}

Note: Numbers in the same column followed by the same letter were not significantly different according to DMRT at $\alpha=5 \%$, DAT was the days after treatment 


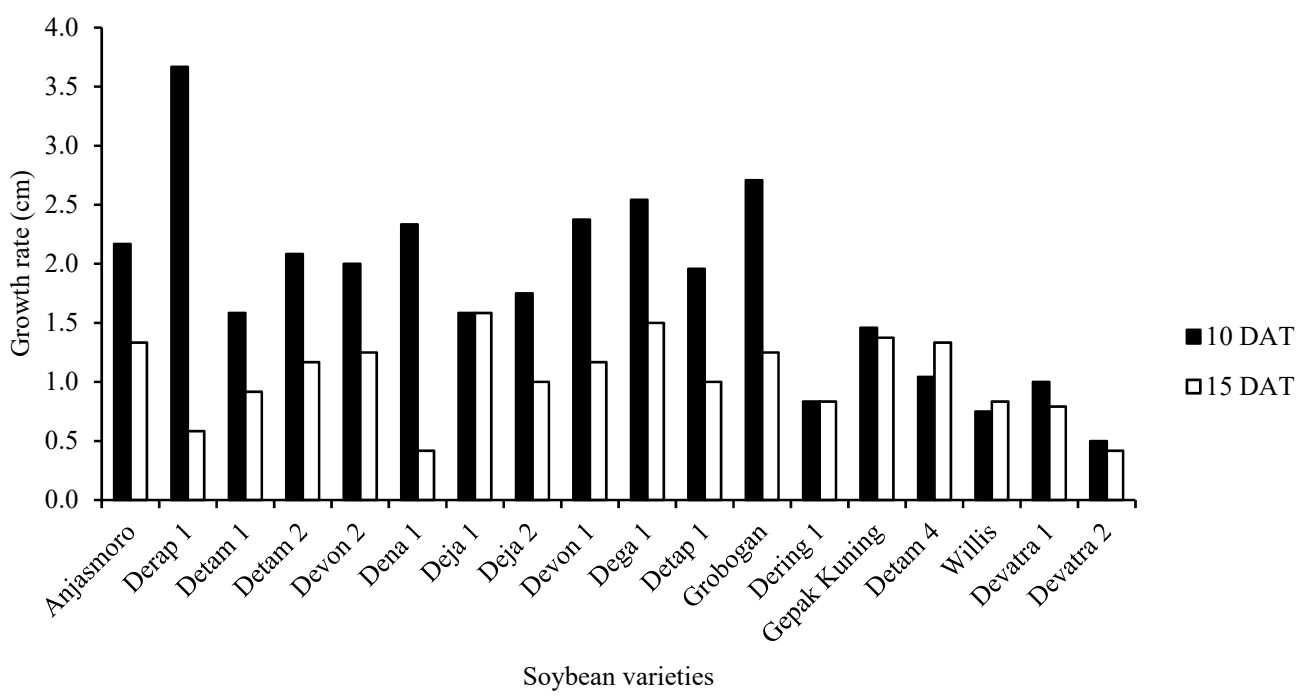

Figure 1. The rate growth of height 18 soybean varieties at 5 to 15 DAT in saline condition

undergo chlorophyll destruction, shown by reducing the leaf's green color. Wibowo and Armaniar (2019) explain that in physiology, salinity tolerance in soybeans have a hight ion $\mathrm{K}^{+}$that influence chlorophyll. This experiment indicated that Devon-1, Detam 1 and Gepak Kuning were the most tolerant genotype while Devatra-1 was the most sensitive one.

Table 2. Leaf greenness, root length, shoot fresh weight, shoot dry weight, root fresh, and root dry weight of 18 soybean varieties at 5,10 , and $15 \mathrm{DAT}$

\begin{tabular}{lcccccccc}
\hline \multirow{2}{*}{ Variety } & \multicolumn{3}{c}{ Leaf greenness } & $\begin{array}{c}\text { Root length } \\
(\mathrm{cm})\end{array}$ & $\begin{array}{l}\text { Shoot fresh } \\
\text { weight }(\mathrm{g})\end{array}$ & $\begin{array}{l}\text { Shoot dry } \\
\text { weight }(\mathrm{g})\end{array}$ & $\begin{array}{l}\text { Root fresh } \\
\text { weight }(\mathrm{g})\end{array}$ & $\begin{array}{c}\text { Root dry } \\
\text { weight }(\mathrm{g})\end{array}$ \\
\cline { 2 - 5 } Anjasmoro & 37.20 & $38.83 \mathrm{ab}$ & 33.87 & 8.00 & $3.65 \mathrm{ab}$ & $0.67 \mathrm{abc}$ & $0.62 \mathrm{~d}$ & 0.23 \\
Derap 1 & 28.80 & $35.14 \mathrm{bc}$ & 31.28 & 10.17 & $3.87 \mathrm{a}$ & $0.82 \mathrm{a}$ & $1.11 \mathrm{ab}$ & 0.17 \\
Detam 1 & 28.23 & $34.32 \mathrm{bc}$ & 35.50 & 11.08 & $2.934 \mathrm{abc}$ & $0.51 \mathrm{bc}$ & $0.84 \mathrm{abcd}$ & 0.09 \\
Detam 2 & 34.07 & $34.82 \mathrm{bc}$ & 34.28 & 11.08 & $2.25 \mathrm{bc}$ & $0.65 \mathrm{abc}$ & $0.99 \mathrm{abc}$ & 0.13 \\
Devon 2 & 35.53 & $38.65 \mathrm{ab}$ & 34.50 & 11.67 & $3.57 \mathrm{ab}$ & $0.64 \mathrm{abc}$ & $1.04 \mathrm{ab}$ & 0.15 \\
Dena 1 & 24.48 & $36.85 \mathrm{bc}$ & 35.30 & 10.17 & $2.22 \mathrm{bc}$ & $0.44 \mathrm{c}$ & $0.66 \mathrm{~cd}$ & 0.09 \\
Deja 1 & 35.92 & $36.17 \mathrm{bc}$ & 28.67 & 12.00 & $2.75 \mathrm{abc}$ & $0.53 \mathrm{bc}$ & $0.95 \mathrm{abc}$ & 0.13 \\
Deja 2 & 35.12 & $34.28 \mathrm{bc}$ & 33.85 & 9.75 & $3.24 \mathrm{abc}$ & $0.72 \mathrm{ab}$ & $0.76 \mathrm{bcd}$ & 0.12 \\
Devon 1 & 35.55 & $41.13 \mathrm{a}$ & 34.24 & 10.17 & $3.78 \mathrm{a}$ & $0.71 \mathrm{ab}$ & $0.86 \mathrm{abcd}$ & 0.14 \\
Dega 1 & 36.63 & $37.77 \mathrm{ab}$ & 34.00 & 11.25 & $1.78 \mathrm{c}$ & $0.45 \mathrm{c}$ & $0.81 \mathrm{abcd}$ & 0.12 \\
Detap 1 & 36.38 & $37.65 \mathrm{ab}$ & 36.50 & 12.00 & $2.52 \mathrm{abc}$ & $0.65 \mathrm{abc}$ & $0.82 \mathrm{abcd}$ & 0.10 \\
Grobogan & 35.22 & $36.48 \mathrm{bc}$ & 32.47 & 11.83 & $2.51 \mathrm{abc}$ & $0.56 \mathrm{bc}$ & $0.89 \mathrm{abcd}$ & 0.10 \\
Dering 1 & 35.00 & $35.65 \mathrm{bc}$ & 31.67 & 12.50 & $2.60 \mathrm{abc}$ & $0.55 \mathrm{bc}$ & $1.10 \mathrm{ab}$ & 0.15 \\
Gepak kuning & 35.50 & $35.60 \mathrm{bc}$ & 36.37 & 12.00 & $3.55 \mathrm{ab}$ & $0.64 \mathrm{abc}$ & $1.10 \mathrm{ab}$ & 0.15 \\
Detam 4 & 33.47 & $34.43 \mathrm{bc}$ & 36.43 & 11.00 & $2.90 \mathrm{abc}$ & $0.54 \mathrm{bc}$ & $1.05 \mathrm{ab}$ & 0.12 \\
Willis & 35.63 & $35.68 \mathrm{bc}$ & 34.83 & 9.08 & $3.14 \mathrm{abc}$ & $0.52 \mathrm{bc}$ & $0.77 \mathrm{bcd}$ & 0.10 \\
Devatra 1 & 32.97 & $32.77 \mathrm{c}$ & 29.97 & 9.17 & $2.91 \mathrm{abc}$ & $0.62 \mathrm{abc}$ & $1.11 \mathrm{ab}$ & 0.12 \\
Devatra 2 & 33.50 & $34.43 \mathrm{bc}$ & 29.57 & 10.58 & $3.96 \mathrm{a}$ & $0.74 \mathrm{ab}$ & $1.14 \mathrm{a}$ & 0.18 \\
\hline
\end{tabular}

Note: Numbers in the same column followed by the same letter was not siginifacantly different according to DMRT at $\alpha=5 \%$, DAT was the days after treatment 


\section{Effect of $\mathrm{NaCl}$ Solutions on Crop Growth}

Salinity stress $\left(6 \mathrm{dSm}^{-1} \mathrm{NaCl}\right)$ significantly reduced crop growth, as shown by reduction in plant height, leaf number, leaf greenness, shoot fresh weight, shoot dry weight, root length, root fresh weight, and root dry weight at all sampling observations (Table 3; Table 4). These data suggested that $\mathrm{NaCl}$ concentration at $6 \mathrm{dSm}^{-1}$ could be used effectively to mimic the effect of salinity stress on soybean seedlings. The same treatment has also been used by Krishnamurthy et al. (2007) on sorghum crops and by Tavakoli et al. (2012) on barley crops. Our findings were in line with a previous report (Ghassemi-Golezani et al., 2011) showing that increasing salinity levels from $3 \mathrm{dSm}^{-1}$ to 6 $\mathrm{dSm}^{-1}$ significantly reduced plant height, leaf number, total biomass but promoted leaf senescence.

Leaf greenness was significantly reduced at all sampling times (Table 4) when soybean was exposed to $6 \mathrm{dSm}^{-1} \mathrm{NaCl}$. The greenness at $0 \mathrm{dSm}^{-1}$ and $6 \mathrm{dSm}^{-1}$ treatments were different when 10 DAT. The effect of salinity appeared begin at 10 DAT. Similar results have been reported by Paterson and Murphy (2015) on the Kinoa plant (Chenopodium quinoa Willd.) when they increase the level of $\mathrm{NaCl}$ from 0 to $32 \mathrm{dSm}^{-1}$. Working on soybean, Egamberdieva et al. (2015) also found that after 42 days exposed to $75 \mathrm{mM} \mathrm{NaCl}$ showed severe stress (inhibited shoot, root growth and nodulation) compared with normal environment. However, the tolerant genotypes showed green leaf and better root growth.

The salinity $6 \mathrm{dSm}^{-1}$ effect's reduced the root length, shoot fresh weight, shoot dry weight, fresh root weight, and root dry weight soybean. The highest drop rate was shoot fresh weight by $76.59 \%$. Salinity reduce the root length
$15.59 \%$ with the results that reduce the fresh root weight until $37.16 \%$. The salinity reducing the weight of shoot and root of wheat (Singh et al., 2015). Fresh mass soybean decreased

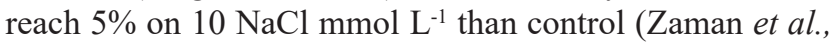
2021). The decrease of plant growth is caused by damage to photosynthesis, protein biosynthesis and the calcium signaling pathway in saline conditions so that the NADP dehydrogenase is regulated down (Miransari, 2016).

\section{Stress Tolerance Index (STI)}

Stress tolerance index (STI) has been used to determine the degree of crop tolerance exposed by comparing the performance of a particular genotype exposed to abiotic stress to that at an optimum growth condition. It has been used to evaluate the version of rice grown at peatland (Haryoko et al., 2012) and the oil palm tree (Supena et al., 2014). In this experiment, STI evaluation showed that there were one category of crop response to salinity stress (Table 5). 18 soybean varieties were tolerant at $6 \mathrm{dSm}^{-1}$. The soybean was classified as a moderately tolerant of salinity higher than 5 $\mathrm{dSm}^{-1}$ and every variety of soybean is different tolerance on saline conditions (Miransari, 2016). So this experiment found that 18 soybean varieties tolerant salinity depend on growth that were plant height, leaf number, branch number, leaf greenness, root length, shoot fresh weight, shoot dry weight, fresh root weight, and root dry weight..

Figure 2 and Figure 3 demonstrated the performance of Deja, Grobogan, Devatra-2 and Devon-2 were tolerant. Although, when exposed to $6 \mathrm{dSm}^{-1} \mathrm{NaCl}$, Deja and Grobogan grew well, while Devatra-2 and Devon-2 showed little of necrotic leaf.

Table 3. Plant height, leaf number, and branch number observed 18 soybean varieties at 5,10 , and $15 \mathrm{DAT}$ of $\mathrm{NaCl}$ concentration

\begin{tabular}{lccccccccc}
\hline \multirow{2}{*}{$\begin{array}{l}\mathrm{NaCl} \\
\left(\mathrm{dSm}^{-1}\right)\end{array}$} & \multicolumn{3}{c}{ Plant height $(\mathrm{cm})$} & \multicolumn{3}{c}{ Leaf number (blade) } & \multicolumn{3}{c}{ Branch number } \\
\cline { 2 - 11 } & 5 DAT & 10 DAT & 15 DAT & 5 DAT & 10 DAT & 15 DAT & 5 DAT & 10 DAT & 15 DAT \\
\hline 0 & $11.65 \mathrm{a}$ & $14.32 \mathrm{a}$ & $15.00 \mathrm{a}$ & $1.81 \mathrm{a}$ & $2.40 \mathrm{a}$ & $2.83 \mathrm{a}$ & 0,09 & 0.15 & 0.26 \\
6 & $10.19 \mathrm{~b}$ & $10.55 \mathrm{~b}$ & $10.83 \mathrm{~b}$ & $1.09 \mathrm{~b}$ & $1.44 \mathrm{~b}$ & $1.48 \mathrm{~b}$ & 0 & 0.09 & 0.11 \\
\hline
\end{tabular}

Note: DAT = days after treatment, numbers in the same column followed by the same letter were not significantly different based on F-test at $\alpha=5 \%$

Table 4. Leaf greenness, root length, shoot fresh weight, shoot dry weight, fresh root weight, and root dry weight of $\mathrm{NaCl}$ concentration on 18 soybean varieties

\begin{tabular}{|c|c|c|c|c|c|c|c|c|}
\hline \multirow{2}{*}{$\begin{array}{l}\mathrm{NaCl} \\
\left(\mathrm{dSm}^{-1}\right)\end{array}$} & \multicolumn{3}{|c|}{ Leaf greenness } & \multirow{2}{*}{$\begin{array}{l}\text { Root length } \\
(\mathrm{cm})\end{array}$} & \multirow{2}{*}{$\begin{array}{l}\text { Shoot fresh } \\
\text { weight (g) }\end{array}$} & \multirow{2}{*}{$\begin{array}{l}\text { Shoot dry } \\
\text { weight }(\mathrm{g})\end{array}$} & \multirow{2}{*}{$\begin{array}{l}\text { Root fresh } \\
\text { weight }(\mathrm{g})\end{array}$} & \multirow{2}{*}{$\begin{array}{c}\text { Root dry } \\
\text { weight }(\mathrm{g})\end{array}$} \\
\hline & $5 \mathrm{DAT}$ & $10 \mathrm{DAT}$ & 15 DAT & & & & & \\
\hline 0 & 34.36 & $37.43 \mathrm{a}$ & $35.79 a$ & $11.55 \mathrm{a}$ & $4.87 \mathrm{a}$ & $0.89 a$ & $1.13 \mathrm{a}$ & $0.17 \mathrm{a}$ \\
\hline 6 & 33.44 & $34.85 \mathrm{~b}$ & $31.13 b$ & $9.98 b$ & $1.14 \mathrm{~b}$ & $0.32 \mathrm{~b}$ & $0.71 b$ & $0.09 \mathrm{~b}$ \\
\hline
\end{tabular}

Note: DAT = days after treatment, numbers in the same column followed by the same letter were not significantly different based on F-test at $\alpha=5 \%$ 


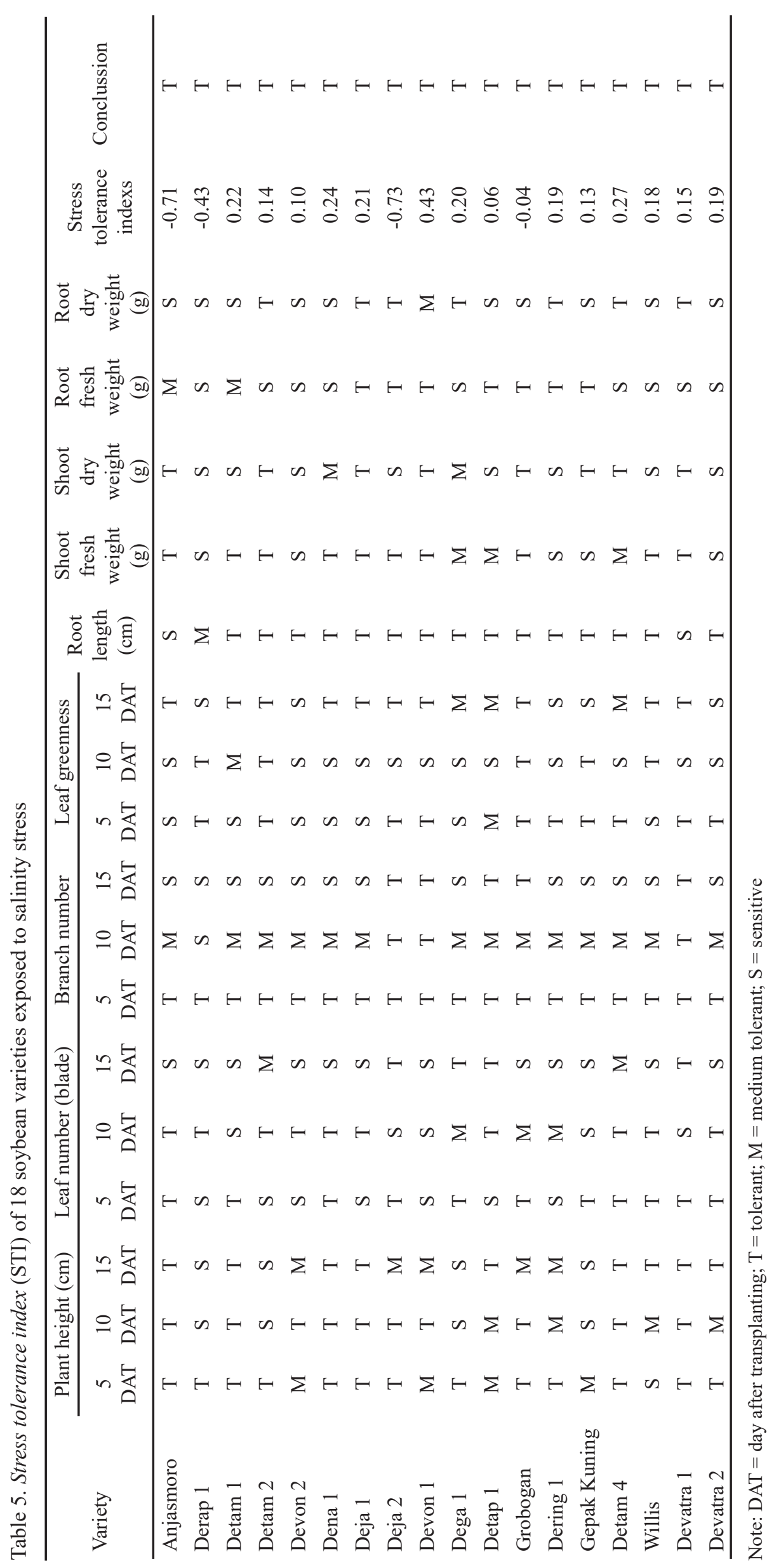




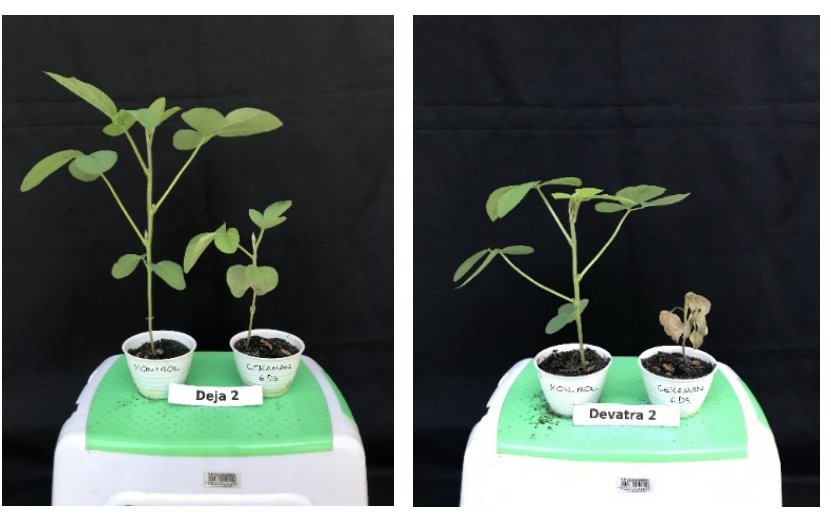

Figure 2. Morphological performance of Deja 2 and Devatra 2 at 15 DAT

\section{CONCLUSION}

Soybean varieties have different crop growth as responses to salinity. Salinity stress, imposed by $6 \mathrm{dSm}^{-1}$ $\mathrm{NaCl}$, significantly reduced crops growth and promoted leaf senescence. We found that 18 soybeans varieties respon to salinity stress were tolerant. We recommend carrying out a field experiment to investigate further the response of these soybean varieties to salinity stress and investigate the mechanism of stress tolerance to salinity.

\section{ACKNOWLEDGEMENT}

The author offers their gratitude to the University of Bengkulu for fully funding this research under Penelitian Unggulan UNIB for 2021 with the contract number 1780/ UN30.15/PG/2021.

\section{REFERENCES}

Aini, N., Syekhfani, Sumiya, W., Dyah, R.P., Setiawan, A. 2014. Growth and physiological characterictics of soybean genotypes (Glycine $\max$ L.) toward salinity stress. Agrivita 36:201-209.

Badan Pusat Statistik. 2020. Impor Kedelai menurut Negara Asal Utama 2010-2019. Badan Pusat Statistik, Jakarta. http://www.bps.go.id.

Bai, X., L. Dai, H. Sun, M. Chen, Y. Sun. 2019. Effects of moderate soil salinity on osmotic adjusment and energy strategy in soybean under drought stress. Plant Physiol. Biochem. 139:307-313.

Chen, H., X. Liu, H. Zhang, X. Yuan, H. Gu, X. Cui, X. Chen. 2018. Advances in salinity tolerance of soybean : genetic diversity, heredity, and gene identification contribute to improving salinity tolerance. J. Integrative Agric. 17:2215-2221.
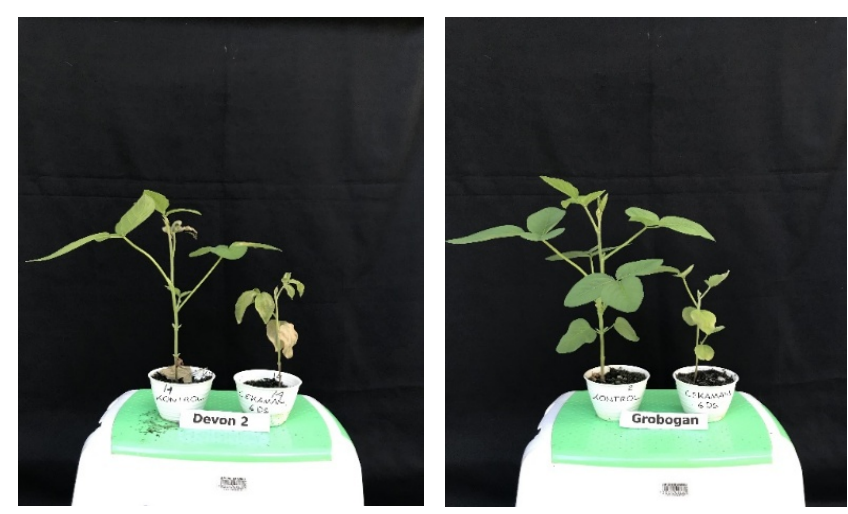

Figure 3. Morphological performance of Devon 2 and Grobogan at 15 DAT

Chinnusamy, V., A. Jagendorf, J.K.Zhu. 2005. Understanding and Improving Salt Tolerance in Plants. Crop Sci. 45:437-448.

Dhairyasheel, B., B. Sharad. 2015. Influence of $\mathrm{NaCl}$ mediated salinity stress on lipid peroxidation in germinating seeds of the soybean. Internat. J. Pharma Bio. Sci. 6:549-552.

Egamberdieva, D., D. Jabborova, G. Berg. 2015. Synergitic interactions between Bradyrhizobium japonicum and the endophyte Stenotrophomonas rhizophila and their effects on growth, and nodulation of soybean under salt stress. Plant Soil. Springer International Publishing, Switzerland. Doi:10.1007/s11104-0152661-8.

Farooq, M., M. Hussain, A. Wakeel, K.H.M. Siddique. 2015. Salt stress in maize: effects, resistance mechanisms, and management. a review. Agron. Sustain. Dev. $35: 461-481$.

Ghassemi-Golezani, K., M. Taifeh-Noori, S. Oustan, M. Moghaddam. S.S. Rahmani. 2011. Physiological performance of soybean cultivars under salinity stress. J. Plant Physiol. Breeding 1:1-7.

Gupta, B., B. Huang. 2014. Mechanism of salinity tolerance in planta : physiological, biochemical and molecular characterization. Int. J. Genomics 2014:18.

Ibrahim, E.A. 2016. Seed priming to alleviate salinity stress in germinating. J. Plant. Physiol. 192:38-46.

Hamayun, M., S.A. Khan, A.L. Khan, Z.K. Shinwari, J. Hussain, E. Sohn, S.M. Kang, Y.H. Kim, M.A. Khan, I.J. Lee. 2010. Effect of salt stress on growth attributes and endogenous growth hormones of soybean cultivar Hwangkeumkong. Pak. J. Bot. 42:3103-3112. 
Haryoko, W., Kasli, I. Suliansyah, A. Syarif, T.B. Prasetyo. 2012. Toleransi beberapa varietas padi pada sawah gambut berkorelasi dengan kandungan asam fenolat. J. Agron. Indonesia 40:112-118.

Kementerian Pertanian. 2018. Outlook kedelai komoditas pertanian subsektor tanaman pangan. pusat data dan sistem informasi pertanian. Kementerian Pertanian.

Khojely, D.M., S.E. Ibrahim, E. Sapey, T.F. Han. 2018. History, current status, and prospects of soybean production and research in sub-saharan Africa. Crop J. 6:226-235.

Kordrostami, M., B. Rabiei. 2019. Salinity stress tolerance in plants: physiological, molecular, and biotechnological approaches. p.1 01-127. In Hasanuzzaman (Eds). Plant Abiotic Stress Tolerance Springer Nature Switzerland.

Koyro, H.W., P. Ahmad, N. Geissler. 2012. Abiotic stress responses in plants: an overview. In P. Ahmad, M.N.V. Prasad (Eds). Environmental Adaptations and Stress Tolerance of Plants in the Era of Climate Change. Springer, New York, US.

Krishnamurthy, L., R. Serraj, C.T. Hash, A.J. Dakheel, B.V. Reddy. 2007. Screening sorghum genotypes for salinity tolerant biomass production. Euphytica 156:15-24.

Le, L.T.T., L. Kotula, K.H.M. Siddique, T.D. Colmer. 2021. $\mathrm{Na}+$ and/or Cl-toxicities determine salt sensitivity in soybean (Glycine max (L.) Merr.), mungbean (Vigna radiata (L.) R. Wilczek), cowpea (Vigna unguiculata (L.) Walp.), and common Bean (Phaseolus vulgaris L.). Int. J. Mol. Sci. 22:1-28.

Liang, W., X. Ma, P. Wan, L. Liu. 2018. Plant salt tolerant mechanism: a review. Biochem. Biophys. Res. Commun. 495:286-291.

Miransari, M. 2016. Soybean, protein, and oil production under stress. p. 157-176. In Miransari, M. (Eds). Abiotic and Biotic Stresess in Soybean Production. Academic Press. Elsevier. Isfahan, IR.

Muscolo, A., M. Sidari, C. Santonoceto, C. De Santis. 2004. Kikuyu grass: effects of salinity and acidity on growth, biochemistry, and root morphology. Recent Research Development in Agron Hort. 1:89-101.

Ohki, K. 1987. Aluminum stress on sorghum growth and nutrient relationships. Plant Soil 98:195-202.

Paparella, S., S.S. Araujo, G. Rossi, M. Wijayasinghe, D. Carbonera, A. Balestrazzi. 2015. Seed priming: state of the art and new perspectives. Plant Cell Reports 34:1281-1293.
Parihar, P., S. Singh, V.P. Singh, S.M. Prasad. 2015. Effect of salinity stress on plants and its tolerance strategies: a review. Environ. Sci. Pollut. Res. 22:4056-4075.

Peterson, A., K. Murphy. 2015. Tolerance of lowland quinoa cultivars to sodium chloride and sodium sulfate salinity. Crop Science. 55:331-338.

Rachman, A., I.G.M. Subiksa, Wahyunto. 2013. Perluasan areal tanaman kedelai kelahan suboptimal. P. 185204. In Sumarno, Suyamto, A. Widjono, Hermanto, H. Kasim $(E d s)$. Kedelai Teknik Produksi dan Pengembangan. Badan Penelitian dan Pengembangan Pertanian.

Rasool, S., A. Ahmad, T.Q. Siddiqi, P. Ahmad. 2013. Change in growth, lipid peroxidation, and some key antioxidant enzymes in chickpea genotype under salt stress. Acta Physiol. Plant. 35:1039-1050.

Rustinah, A, Taufiq, R. Iswanto. 2018. Evaluasi toleransi genotipe kacang hijau terhadap cekaman salinitas. J. Agron. Indonesia 46:269-275.

Singh, D., P.C. Ram, A. Singh, Y.P. Singh, P.C. Sharma, S. Srivastava. 2015. Alleviating adverse effect of soil salinity $\mathrm{n}$ biomass production and physiological changes in wheat (Triticum aestivum L.) through application of zinc fertilizer. Res. Environ. Life Sci. 8:251-254.

Supena, N., A. Soegianto, L. Soetopo. 2014. Response of oil palm varieties to aluminum stress. J. Trop. Life Sci. 4:51-60.

Taufiq, A., Nugrahaeni, N., Susanto, G.W.A. 2019. Evaluasi toleransi sumber daya genetik kedelai terhadap cekaman salinitas. Bul. Palawija 17:10-20.

Tavakkoli, E., F. Fatehi, P. Rengasamy, G.K. McDonald. 2012. A comparison of hydroponic and oil-based screening methods to identify salt tolerance in the field in barley. J. Exp. Botany 63:3853-3868.

Wibowo, F., Armaniar. 2019. Prediction of gene action content of $\mathrm{Na}, \mathrm{K}$, and chlorophyll for soybean crop adaptation to salinity. Jerami Indonesian J. Crop. Sci. 2:21-28.

Zaman, B., Z. Gul, M. Suhaib, M. Ishaq, H. Khurshid. 2021. Vegetative growth and ion relations in soybean with potassium sulphate application under saline environment. Asian Soil Rec. J. 5:1-9.

Zorb, C., C.M. Geilfus, K.J. Dietz. 2019. Salinity and crop yield. Plant Biology 21:31-38. 